\title{
RIGHTS TO EDUCATION FOR POOR PEOPLE: HOW THE COUNTRY PROTECT THEM?
}

\author{
Luthfi Widyantoko \\ Community of Education Rights for Marginal People \\ Email: luthfiwidiyantoko@gmail.com
}

\begin{abstract}
This paper discusses the rights of the poor and marginalized in obtaining the right to education as one of the basic human rights. This paper is based on the condition that the urgency of educational development is one of the top priorities in the national development agenda. Educational development is very important because of its significant role in achieving progress in various fields of life: social, economic, political, and cultural. Therefore, the Government is obliged to fulfill the rights of every citizen in obtaining education services in order to improve the quality of life of the Indonesian people as mandated by the 1945 Constitution, which requires the Government to be responsible in educating the life of the nation and creating public welfare. The lack of equal distribution of education in Indonesia is a classic problem which until now there has not been any strategic steps from the government to handle it. This paper confirms that the achievement of the right to education in Indonesia has not been achieved and is motivated by several key factors, among government policies. In addition, human resources and infrastructure are also one of the causes of unequal access to education in Indonesia.
\end{abstract}

Keywords: Rights to Education, Poor people, Policy, Human Rights

The Indonesian Journal of International Clinical Legal Education DOI: 10.15294/ijicle.v2il.37322

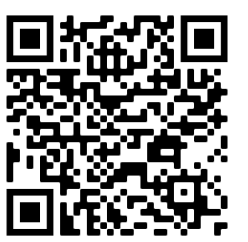


Widyantoko

\section{PENDAHULUAN}

Hak Asasai Manusia (HAM) mempunyai arti penting bagi kehidupan manusia, terutama dalam hubungan antara negara dan warga negara, dan dalam hubungan antara sesama warga negara. HAM merupakan hak dasar yang dimiliki manusia sejak manusia itu dilahirkan yang diperoleh manusia dari Tuhan YME dan merupakan hak yang tidak dapat diabaikan. HAM tidak dapat digganggu gugat oleh siapapun karena HAM bersifat kodrati dan berlaku sepanjang hidup manusia.Para ahli HAM menyatakan bahwa sejarah perkembangan HAM bermula dari kawasan Eropa. Wacana awal HAM di Eropa yang dimulai dengan lahirnya Magna Charta di Inggris pada 15 Juni $1215 .^{1}$ Perkembangan HAM selanjutnya ditandai dengan dua peristiwa dalam sejarah dunia yang menghasilkan rumusan yang mirip dengan rumusan hak-hak asasi manusia yaitu Revolusi Amerika yang dimulai pada tahun 1776 dan Revolusi Perancis pada tahun 1789. Sejarah besar perkembangan HAM selanjutnya ditandai dengan perumusan Deklarasi Universal HAM (DUHAM) yang dikukukan oleh PBB dalam Universal Declaration of Human Rights (UDHR) pada tanggal 10 Desember 1948.

Di Indonesia, HAM bersumber dan bermuara pada pancasila. Bagi bangsa Indonesia, melaksanakan Hak Asasi Manusia bukan berarti melaksanakan dengan sebebas-bebasnya, melainkan harus memperhatikan ketentuan-ketentuan yang terkandung dalam pandangan hidup bangsa Indonesia, yaitu Pancasila.

Setiap hak akan dibatasi oleh hak orang lain. Jika dalam melaksanakan hak tidak memperhatikan hak orang lain, maka yang terjadi adalah benturan hak atau kepentingan dalam hidup bermasyarakat, berbangsa, dan bernegara atau dengan kata lain dapat menimbulkan kasus-kasus pelanggaran HAM. Kasus-kasus pelanggaran HAM bisa saja terjadi di berbagai bidang kehidupan, tidak terkecuali di bidang pendididikan.

Seiring dengan perkembangan zaman, kemajuan pembangunan di Indonesia dalam segala bidang berkembang pesat pula. Tidak terkecuali pembangunan dalam hal bidang pendidikan. Hal ini merupakan upaya yang sungguh-sungguh dari rakyat untuk mencapai suatu kehidupan yang dicita-citakan, yaitu mencerdaskan kehidupan bangsa berdasarkan Pancasila dan UUD 1945. Untuk mencapai cita-cita bangsa dalam mencerdaskan kehidupan bangsa, sangatlah diperlukan pemenuhan hak atas pendidikan yang layak bagi seluruh warga negara Indonesia. Yang dimaksut dengan pendidikan tercantum dalam Pasal 1 ayat (1)UndangUndang Nomor 20 Tahun 2003 tentang Sistem Pendidikan Nasional yang berbunyi, "Pendidikan adalah usaha sadar dan terencana untuk mewujudkan suasana belajar dan proses pembelajaran agar peserta didik secara aktif mengembangkan potensi dirinya untuk memiliki kekuatan

Setiardja, Gunawan. 1993. Hak-hak Asasi Manusia Bedasarkan Ideologi Pancasila. Yogyakarta : Kanisus, hlm. 12 
spiritual keagamaan, pengendalian diri, kepribadian, kecerdasan, akhlak mulia, serta keterampilan yang diperlukan dirinya, masyarakat, bangsa dan Negara".

Pembangunan pendidikan merupakan salah satu prioritas utama dalam agenda pembangunan nasional. Pembangunan pendidikan sangat penting karena perannya yang signifikan dalam mencapai kemajuan di berbagai bidang kehidupan: sosial, ekonomi, politik, dan budaya. Karena itu, Pemerintah berkewajiban untuk memenuhi hak setiap warga negara dalam memperoleh layanan pendidikan guna meningkatkan kualitas hidup bangsa Indonesia sebagaimana diamanatkan oleh UUD 1945, yang mewajibkan Pemerintah bertanggung jawab dalam mencerdaskan kehidupan bangsa dan menciptakan kesejahteraan umum. Kurang meratanya pendidikan di Indonesia menjadi suatu masalah klasik yang hingga kini belum ada langkahlangkah strategis dari pemerintan untuk menanganinya.

Hak atas pendidikan sebagai bagian dari hak asasi manusia di Indonesia tidak sekadar hak moral melainkan juga hak konstitusional. Ini sesuai dengan ketentuan UUD 1945 (pascaperubahan), khususnya Pasal $28 \mathrm{C}$ Ayat (1) yang menyatakan, "Setiap orang berhak mengembangkan diri melalui pemenuhan kebutuhan dasarnya, berhak memperoleh pendidikan dan memperoleh manfaat dari ilmu pengetahuan dan teknologi, seni dan budaya, demi meningkatkan kualitas hidupnya dan demi kesejahteraan umat manusia."Selain ketentuan di atas, Pasal 31 ayat (2) UUD 1945 (pasca perubahan) juga merumuskan bahwa setiap warga Negara wajib mengikuti pendidikan dasar, sedangkan pemerintah wajib membiayainya. Pasal 31 ayat (3) dan (4) menegaskan bahwa pemerintah memiliki kewajiban untuk mengusahakan penyelenggaraan pengajaran nasional dalam rangka mencerdaskan kehidupan bangsa dengan memprioritaskan anggaran sekurang-kurangnya 20 persen dari Anggaran Pendapatan dan Belanja Negara (APBN) dan Anggaran Pendapatan dan Belanja Daerah (APBD).Demikian pula ketentuan Ketetapan Majelis Permusyawaratan Rakyat (MPR) Nomor XVII/MPR/1998 tentang Hak Asasi Manusia menegaskan jaminan hak atas pendidikan. Pasal 60 Undang-Undang Nomor 39 Tahun 1999 tentang Hak Asasi Manusia memperkuat dan memberikan perhatian khusus pada hak anak untuk memperoleh pendidikan sesuai minat, bakat dan tingkat kecerdasannya. Penegasan serupa tentang hak warga negara atas pendidikan juga tercantum dalam Undang-Undang Nomor 20 Tahun 2003 tentang Sistem Pendidikan Nasional.

Dalam konteks pemenuhan hak atas pendidikan, negara menjadi pihak utama yang bertanggung jawab untuk menjaminnya. Pada Pasal 53 ayat (1) Undang-Undang Nomor 23 Tahun 2002 tentang Perlindungan Anak terdapat penegasan bahwa negara - dalam hal ini pemerintah memiliki tanggung jawab memberikan biaya pendidikan dan/atau bantuan cuma-cuma atau pelayanan khusus bagi anak dari keluarga tidak mampu, anak terlantar, dan anak yang bertempat tinggal di daerah terpencil.Pendidikan merupakan hak asasi manusia (HAM) dan 


\section{Widyantoko}

merupakan suatu sarana yang mutlak diperlukan untuk mewujudkan hakhak yang lainnya. Penyelesaian suatu program pendidikan yang sudah ditetapkan dengan memuaskan merupakan prasyarat yang sangat penting untuk akses mendapatkan perkerjaan, mendapatkan kehidupan yang layak serta mengangkat harkat dan martabat pribadi seseorang, sehingga pendidikan dilihat sebagai gerbang menuju keberhasilan.

Indonesia pada dasarnya telah meratifikasi instrumen HAM internasional misalnya, Kovenan internasional tentang Hak-Hak Sipil dan Politik, dan Hak-Hak Ekonomi, Sosial dan Kebudayaan. Ratifikasi itu kemudian dituangkan dalam Undang-undang Nomor 11 tahun 2005 tentang pengesahan kovenan Internasional tentang hak-hak ekonomi, sosial dan budaya dan Undang-undang Nomor 12 tahun 2005 tentang pengesahan kovenan tentang internasional tentang hak-hak sipil dan politik. Bersama dengan itu juga terdapat Deklarasi Universal Hak Asasi Manusia (DUHAM), yang telah dideklarasikan oleh Persatuan BangsaBangsa (PBB) untuk membentuk Perjanjian Internasional tentang Hak Asasi Manusia (HAM). Tiga perjanjian internasional lainnya yang menjadi tolok ukur dalam upaya global mencapai tujuan-tujuan pendidikan untuk semua dan secara khusus untuk menghapus diskriminasi dalam pendidikan yaitu: (1) Konvensi UNESCO tentang Penentangan Diskriminasi dalam Pendidikan; (2) Konvensi tentang Penghapusan terhadap Diskriminasi Rasial; dan (3) Konvensi tentang Penghapusan Segala Bentuk Diskriminasi terhadap Wanita. ${ }^{2}$

Negara disini memiliki tanggung jawab besar untuk menghormati (respect), memenuhi (fulfiil), melindungi (protect) hak asasi manusia atas pendidikan seluruh warga negara. Maka dari itu tidak ada alasan untuk memungkiri tidak terpenuhinya hak atas pendidikan anak Indonesia. Karena mereka adalah bagian dari generasi penerus bangsa indonesia kelak untuk mewujudkan apa yang dicita-citakan seperti yang tertera pada pembukaan Undang-undang Dasar Republik Indonesia tahun 1945 sebagai konstitusi negara Indonesia.

Namun pada tataran realitas empiris di lapangan bisa dilhat bahwa, masih banyak anak-anak indonesia yang putus sekolah maupun yang tidak dapat mengenyam hak pendidikan dasar sama sekali. Data empiris pun menunjukkan bahwa hingga akhir 2010, jumlah masyarakat Indonesia yang belum memiliki kemampuan mengenal dan membaca tulisan mencapai sekitar 8,3 juta jiwa, atau sekitar 5\% dari jumlah penduduk Indonesia. ${ }^{3}$

Begitu juga dengan data yang dirilis UNESCO-PBB pada tahun 2011 bahwa, dari 31,05 juta siswa Sekolah Dasar (SD) di Indonesia, tercatat sebanyak 527.850 orang atau $1,7 \%$ yang putus sekolah setiap tahunnya. Dan dari total jumlah penduduk Indonesia usia kuliah (18-25 Tahun) sebesar 25 juta jiwa, hanya 4,6 juta jiwa yang

2 Setiardja, Gunawan. 1993. Hak-hak Asasi Manusia Bedasarkan Ideologi Pancasila. Yogyakarta : Kanisus, hlm. 45

3 Jerome Binde. 2001.Keys to The 21st Century, New York, Unisco, hlm.ix 
berkuliah. Jumlah ini hanya meningkat 3.000 orang dari tahun sebelumnya yang berjumlah 4,3 juta jiwa. Sementara angka putus kuliah mencapai 150.000 orang setiap tahun.

Dari data empiris diatas tidak bisa dikatakan bahwa pemerintah sudah berhasil dalam hal melaksanakan tanggung jawabnya serta menangani anak-anak yang putus sekolah atau tidak bersekolah. Karena masih adanya ribuan anak-anak yang putus sekolah atau tidak bisa bersekolah di Indonesia yang masih berharap untuk mendapatkan hak atas pendidikan sebagai warga negara yang memiliki hak konstitusional dan hak hukum.

Permasalahan anak-anak yang putus sekolah atau tidak bersekolah tersebut karena faktor komersialisasi dan komoditasi pendidikan yang ada di Indonesia. Salah satu contohnya adalah anggaran untuk pendidikan yang dirasakan sangat diskriminatif, adanya pembedaan antara lembaga pendidikan negeri dan lembaga pendidikan swasta. Masyarakat kemudian menganggap wajar jika biaya pendidikan swasta lebih mahal dibandingkan dengan pendidikan negeri. Padahal dalam pasal 31 UUD 1945 mengatur bahwa setiap warga Negara berhak atas pendidikan dan Negara bertanggung jawab untuk menyelenggarakannya tanpa adanya perbedaan status sekolah, baik negeri maupun swasta. Dan bukankah keberadaan lembaga pendidikan swasta dikarenakan terbatasnya lembaga pendidikan negeri.

Berdasarkan data Depdiknas tahun 2009, jumlah SD mencapai 146.393 (91,04\% negeri; 8,96\% swasta), SMP mencapai 23.124 (48,63\% negeri; 51,37\% swasta), SMA mencapai 10.749 (44,51\% negeri; 55, 49\% swasta), dan SMK mencapai 7.586 (26,32\% negeri; 73,68\% swasta). Dari data tersebut, jika anggaran pendidikan hanya diperuntukkan bagi sekolah negeri, maka banyak rakyat Indonesia yang tidak akan mendapatkan haknya atas subsidi pendidikan. Masalah di atas merupakan bentuk komersialisasi dan komoditasikebijakan anggaran pendidikan yang inkonstitusional.

Adanya diskriminasi pendidikan tersebut merupakan bentuk pelanggaran hak konstitutional warga negara yang diatur dalam UUD 1945. Apalagi untuk negara Indonesia yang penduduknya sangat majemuk, dimana lagi di dunia ada negara kepulauan yang sarat dengan pluralisme namun tetap terbingkai dalam wadah negara kesatuan. Namun demikian, pada sisi lain multikulturalisme yang dimiliki Indonesia mulai dari rasial, etnis, ekonomi, agama, sosial, budaya yang terus mendapatkan diskriminasi dalam konteks pemenuhan hak atas pendidikan. ${ }^{4}$

Diskriminasi hak atas pendidikan dalam konteks negara Indonesia yang multikulturalisme secara nyata telah mencederai nilainilai keadilan, kemerdekaan, persamaan, martabat, dan hak untuk hidup bebas dari diskriminasi.

$4 \quad$ Soegito, dkk. Pendidikan Pancasila. Semarang : UNNES Press 


\section{Widyantoko}

Dalam menjadi manusia khususnya menjadi warga negara Indonesia kita tidak bisa lepas dari dua hal yaitu kewajiban dan hak kita sebagai warga negara yang baik, kewajiban yang harus kita laksanakan sebagai warga negara yang baik diantaranya ikut mewujudkan cita-cita bangsa Indonesia yang tertuang dalam Pemukaan UUD 1945 alenia $4 .^{5}$

Dan sebagai warga negara Indonesia setelah kita melaksanakan kewajiban kita yaitu diantaranya mendapat kesejahteraan hidup, mendapat perlindungan negara, dan masih banyak lagi. Namun diantara hak-hak yang kita peroleh tadi ada satu hak yang sangat penting bagi kita sebagai warga negara untuk bekal dalam menyongsong hidup zaman era globalisasi ini. Hak yang paling penting itu adalah Pendidikan, mendapatkan pendidikan yang layak sebagai warga negara adalah hal yang sangat utama dalam menjalani hidup terutama dalam menghadapi persaingan yang semakin ketat di era globalisasi ini.

Dalam hidup ini setiap manusia membutuhkan apa yang dinamakan dengan Ilmu, dengan Ilmu tadi setiap manusia dapat berkembang menjadi apa yang ia inginkan, menjadi seperti apa yang ia cita-cita kan, dan mampu bersaing dengan manusia lain dalam berbagai aspek kehidupan. Nah ilmu tadi hanya dapat diperoleh melalui Pendidikan terutama dalam pendidikan formal atau biasa disebut dengan sekolah. Di sekolah-sekolah diajarkan mengenai berbagai tatanan ilmu pengetahuan dan aspek-aspek kehidupan. Diantara tujuan (visi) sekolah salah satunya yaitu mencerdaskan bangsa Indonesia seperti yang tertuang dalam UUD 1945 dan sebagai pelaksanaan pembangunan bangsa yang berkarakter kuat dan cerdas hingga mampu bersaing dengan bangsa lain yang lebih maju. Pasal 31 UUD 1945 mengamanatkan bahwa pendidikan merupakan hak bagi setiap warga negara tetapi pendidikan dasar merupakan kewajiban yang harus diikuti oleh setiap warga negara dan pemerintah wajib membiayai kegiatan tersebut.

Sebagaimana yang diungkapkan Daoed Joesoef tentang pentingnya suatu pendidikan, "Pendidikan merupakan segala bidang penghidupan, dalam memilih dan membina hidup yang baik, yang sesuai dengan martabat manusia". Dari pernyataan tersebut menyatakan bahwa pendidikan merupakan hal yang sangat penting dan tidak bisa lepas dari kehidupan tapi pendidikan juga bukanlah segalanya.

\section{PERAN PENDIDIKAN BERBASIS HAK ASASI MANUSIA (HAM) DI INDONESIA}

Agar terciptanya suatu sistem pendidikan yang berbasiskan HAM, maka diperlukan strategi yang seragam dalam sektor pendidikan dan mencakup hubungan lintas sektoral. Strategi yang harus dilakukan oleh pemerintah adalah dengan cara melaksanakan kewajiban-kewajiban pemerintah

Pidarta, Prof. Dr. Made. 2004. Management Pendidikan Indonesia. Jakarta. PT Rineka Cipta 
berkait dengan hak asasi manusia agar pendidikan dapat disediakan (available), dapat dijangkau (accessible), dapat diterima (acceptable) dan dapat disesuaikan (adaptable).

Tabel 1. Kewajiban dan Tanggung Jawab Pemerintah Terkait Hak Atas Pendidikan

\begin{tabular}{|c|c|}
\hline Aspek & Tanggung Jawab dan Kewajiban Pemerintah \\
\hline \multirow[t]{2}{*}{$\begin{array}{l}\text { Ketersediaan } \\
\text { (Availability) }\end{array}$} & $\begin{array}{l}\text { Kewajiban untuk menjamin wajib belajar dan } \\
\text { pendidikan tanpa biaya bagi seluruh anak usia } \\
\text { sekolah bagi suatu negara, sampai sekurang- } \\
\text { kurangnya usia minimum untuk diperbolehkan } \\
\text { bekerja. }\end{array}$ \\
\hline & $\begin{array}{l}\text { Kewajiban untuk menghargai kebebasan orang tua } \\
\text { untuk memilihkan pendidikan bagi anak-anaknya, } \\
\text { dengan mempertimbangkan minat anak yang } \\
\text { bersangkutan. }\end{array}$ \\
\hline \multirow[t]{2}{*}{$\begin{array}{l}\text { Keterjangkauan } \\
\text { (Accessibility) }\end{array}$} & $\begin{array}{l}\text { Kewajiban untuk menghapuskan eksklusivitas } \\
\text { pendidikan berdasarkan pelarangan terhadap } \\
\text { diskriminasi (suku, warna kulit, jenis kelamin, } \\
\text { bahasa, agama, opini, asal, status ekonomi, } \\
\text { kelahiran, status sosial, status minoritas atau } \\
\text { penduduk asli, berkemampuan kurang). }\end{array}$ \\
\hline & $\begin{array}{l}\text { Kewajiban untuk menghapuskan diskriminasi jender } \\
\text { dan rasial dengan menjamin pemberian kesempatan } \\
\text { yang sama dalam pemenuhan hak asasi manusia, } \\
\text { daripada hanya secara formal melarang } \\
\text { diskriminasi. }\end{array}$ \\
\hline \multirow[t]{3}{*}{$\begin{array}{l}\text { Kesesuaian } \\
\text { (Adaptability) }\end{array}$} & $\begin{array}{l}\text { Kewajiban untuk merencanakan dan } \\
\text { mengimplementasikan pendidikan bagi anak yang } \\
\text { tidak mengikuti sekolah formal (misalnya, } \\
\text { pendidikan bagi anak di pengungsian atau } \\
\text { pengasingan, pendidikan bagi anak-anak yang } \\
\text { kehilangan kebebasannya, atau pendidikan bagi } \\
\text { pekerja anak). }\end{array}$ \\
\hline & $\begin{array}{l}\text { Kewajiban untuk menyesuaikan pendidikan dengan } \\
\text { minat utama setiap anak, khususnya bagi mereka } \\
\text { dengan kelainan, atau anak minoritas dan penduduk } \\
\text { asli. }\end{array}$ \\
\hline & $\begin{array}{l}\text { Kewajiban untuk mengaplikasikan hak asasi } \\
\text { manusia secara utuh sebagai pedoman sehingga } \\
\text { dapat memberdayakan hak asasi manusia melalui } \\
\text { pendidikan, misalnya hak untuk kawin dan }\end{array}$ \\
\hline
\end{tabular}


Widyantoko

\begin{tabular}{ll}
\hline & $\begin{array}{l}\text { membentuk keluarga, atau hak untuk terbebas dari } \\
\text { tekanan dan dipekerjakan. }\end{array}$ \\
\hline Keberterimaan & $\begin{array}{l}\text { Kewajiban untuk menetapkan standar minimum } \\
\text { pendidikan, termasuk bahasa pengantar, materi, } \\
\text { (Acceptability) } \\
\text { metode mengajar, dan untuk menjamin } \\
\text { penerapannya pada semua lembaga pendidikan. }\end{array}$
\end{tabular}

Kewajiban untuk meningkatkan mutu pendidikan dengan menjamin bahwa seluruh sistem pendidikan sejalan dengan hak asasi manusia.

\section{PERMASLAHAN BELUM TERCAPAINYA PENDIDIKAN YANG MERATA DI INDONESIA}

Di Indonesia, yang paling memerlukan pendidikan adalah mereka yang berada di daerah miskin dan terpencil. Untuk mengatasi kebutuhan pendidikan bagi mereka adalah upaya penerapan cara non konvensional. Cara lain itu adalah memanfaatkan potensi, kemajuan serta keluwesan teknologi baru. Sekalipun teknologi baru seperti teknologi komunikasi, informasi dan adi-marga menawarkan pemerataan pendidikan dengan biaya yang relatif rendah, penggunaannya masih merupakan jurang pemisah antara yang kaya dan yang miskin. Di samping itu, sekalipun teknologi dapat menjangkau yang tak terjangkau serta dapat menghadirkan pendidikan kepada warga belajar, mereka yang terlupakan tetap dirugikan karena bukan hanya tetap buta teknologi tetapi tertinggal dalam hal ilmu pengetahuan.

Mayoritas kaum miskin di Indonesia tinggal di tempat-tempat jauh yang terpencil. Mereka praktis kekurangan segalanya; fasilitas, alatalat transportasi dan komunikasi di samping rendahnya pengetahuan mereka terhadap teknologi. Bila pendidikan ingin menjangkau mereka yang kurang beruntung ini kondisi yang proporsional harus diciptakan dengan memobilasasi sumber-sumber lokal dan nasional. Ketimpangan pemerataan pendidikan juga terjadi antarwilayah geografis yaitu antara perkotaan dan perdesaan, serta antara kawasan timur Indonesia (KTI) dan kawasan barat Indonesia (KBI), dan antartingkat pendapatan penduduk ataupun antargender.

Kurangnya pemerataan dan carut-marut pendidikan kita selama ini disebabkan pendidikan dikelola tidak secara profesional. Terjadi bongkar pasang kebijakan secara tidak konsisten, misalnya; penerapan kurikulum CBSA, Kurikulum Berbasis Kompetensi (KBK) dan kurikulum KTSP. Penggantian nama dari SMA ke SMU kembali lagi ke SMA, sebelum diadakan evaluasi hasil pelaksanaannya.

Terbatasnya ketersediaan buku juga merupakan salah satu faktor terpenting penyelenggaraan pembelajaran yang berkualitas. Namun 
demikian berbagai sumber data termasuk SUSENAS 2004 mengungkapkan bahwa tidak semua peserta didik dapat mengakses buku pelajaran baik dengan membeli sendiri maupun disediakan oleh sekolah.

1. Pemarataan pendidikan formal

2. Pendidikan prasekolah dan sekolah dasar

Pendidikan prasekolah merupakan pendidikan pada anak usia dini, misal : playgroup dan taman kanak-kanak. Pada daerah perkotaan pendidikan prasekolah secara formal sudah sering ditemukan, tetapi untuk daerah terpencil seperti di pedesaan, masih sangat jarang dan mutunya sangat berbeda dengan pendidikan prasekolah yang ada di daerah perkotaan.

Pendidikan sekolah dasar memang sudah cukup dirasakan pemerataannya di berbagai daerah, hal ini sejalan dengan program wajib belajar 9 tahun, tetapi mutu dari pendidikan tersebut masih sangat berbeda antara daerah perkotaan dengan pedesaan.

Ketersediaan buku juga merupakan salah satu faktor sangat penting dalam pelaksanaan kegiatan pembelajaran yang berkualitas, namun buku pelajaran yang diperlukan itu belum tersedia secara memadai, terutama dalam pendidikan dasar. Data Susenas 2004 dan sumber-sumber yang lain mengungkapkan bahwa tidak semua peserta didik dalam pendidikan dasar dapat mengakses buku pelajaran, baik dengan membeli sendiri maupun mendapat pinjaman dari sekolah. Adanya sekolah-sekolah yang membolehkan guru mata pelajaran menjual buku yang berharga tinggi juga menjadi permasalahan tersendiri. Penjualan buku-buku dengan harga yang cukup tinggi membuat masyarakat yang kurang mampu merasa terbebani.

Dalam dunia pendidikan, terdapat banyak instansi-instansi yang bukan berbadan pemerintah atau dalam kata lain mereka berbadan yayasan sehingga biaya pendidikan dalam badan yayasan ini dirasa sangat mahal dan membebani masyarakat. Sehingga persaingan dalam mencari sekolah atau lembaga pendidikan yang berbadan Negeri (bukan swasta) menjadi semakin ketat sehingga banyak peserta didik yang dalam artian hanya yang memiliki kecerdasan lebih lah yang mampu memenangkan persaingan tersebut. Lalu bagaimanakah nasib mereka yang hanya memiliki IQ dibawah rata-rata. Apakah mereka tidak boleh mendapatkan pendidikan seperti mereka yang cerdas. Adapun beberapa program bagi yang nasib mereka tidak memiliki biaya untuk belajar adapun permasalnya seperti berikut:

\section{A. Dana APBN dan BOS yang tidak jelas arahnya $(K K N)$}

Dana APBN dan BOS yang begitu banyak diberikan Pemerintah untuk mengembangkan pendidikan bagi mereka yang kurang mampu dan juga untuk mensubsidi biaya pendidikan yang dirasa terlalu mahal ternyata jika ditelusuri sampai akhir terdapat keganjilan terhadap arah penggunaan dana tersebut. Ternyata begitu banyak penyalahgunaan dana tersebut yang tidak lain tidak bukan dilakukan oleh pejabat-pejabat yang 


\section{Widyantoko}

bersangkutan. Begitu mirisnya nasib bangsa ini, bangsa yang menginginkan agar penduduknya bisa maju ternyata terdapat kalangan yang mencoba menghambat tujuan tersebut yang begitu mengejutkannya itu dilakukan oleh orang dalam sendiri atau lembaga atau pejabat-pejabat yang ada dalam Pemerintahan Indonesia itu sendiri.

\section{B. Daerah pelosok yang sulit dijangkau (Kondisi Geografis)}

Negara Kesatuan Republik Indonesia terdiri dari beribu-ribu pulau yang dipisahkan oleh lautan dan samudra. Dari pulau-pulau itu terdapat kurang lebihnya 100 pulau terpencil yang didalamnya terdapat berbagai macam suku yang mereka mendiami suatu tempat yang sulit dijangkau oleh orang lain. Dengan begitu mereka yang berada didalamnya juga belum tentu bisa merasakan apa itu yang dinamakan dengan pendidikan. Apakah mereka yang termasuk suku pedalaman tidak boleh mendapat pendidikan seperti mereka yang berada di kota-kota.

\section{Tenaga pendidik yang belum loyal}

Yang dimaksud dengan tenaga pendidik yang belum loyal adalah begitu banyaknya tenaga pendidik (guru) di Negara Indonesia ini tetapi mereka masih belum bisa menunjukkan kwalitas mereka sebagai guru yang baik, maksudnya adalah guru-guru ini banyak yang menyebar diperkotaan namun begitu sedikit yang mau mengabdi di daerah pedalaman sehingga mereka yang berada dipedalaman yang menginginkan pendidikan tidak bisa menikmatnya karena tak adanya tenaga pendidik atau guru yang mau mengabdi sampai sana. Kalaupun ada itu hanya sedikit sekali sehingga sangat sulit dijumpai sekolah atau pun lembaga pendidikan didaerah terpencil seperti di papua.

D. Kurang optimalnya pelaksanaan sistem pendidikan(yang sebenarnya sudah cukup baik) di Indonesia yang disebabkan sulitnya menyediakan guru-guru berkompetensi untuk mengajar di daerah-daerah.

Sebenarnya kurikulum Indonesia tidak kalah dari kurikulum di negara maju, tetapi pelaksanaannya yang masih jauh dari optimal. Kurang sadarnya masyarakat mengenai betapa pentingnya pendidik dalam membentuk generasi mendatang sehingga profesi ini tidak begitu dihargai. Sistem pendidikan yang sering berganti-ganti, bukanlah masalah utama, yang menjadi masalah utama adalah pelaksanaan di lapangan, kurang optimal. Terbatasnya fasilitas untuk pembelajaran baik bagi pengajar dan yang belajar. Hal ini terkait terbatasnya dana pendidikan yang disediakan pemerintah.

Banyak sekali kegiatan yang dilakukan depdiknas untuk meningkatkan kompetensi guru, tetapi tindak lanjut yang tidak membuahkan hasil dari kegiatan semacam penataran, sosialisasi. Jadi terkesan yang penting kegiatan itu terlaksana selanjutnya, tanpa 
memperhatikan manfaat yang dapat diperoleh. Jika kondisi semacam itu tidak diubah untuk dibenahi kecil harapan pendidikan bisa lebih maju/baik.

\section{PENDIDIKAN DI INDONESIA HANYA TERPAKU DI PULAU JAWA SEMISAL DI KOTA BESAR INDONESIA SEPERTI JAKARTA, YOGYAKARTA, SURABAYA}

Perkembangan sarana dan prasarana pendidikan di Indonesia mulai membaik tepatnya di kota-kota besar seperti Jakarta, Yogyakarta dan Surabaya, tetapi kondisi ini tidak diikuti dengan peningkatan sarana dan prasarana sekolah di daerah pedalaman dan perbatasan. Masih banyak sekolah yang sarana dan prasaranya kurang mendukung. Seperti halnya di daerah terpencil yang terdapat di perbatasa Kalimantan,NTT, Papua, mereka disana masih belum memiliki bangunan sekolah yang memadai serta sarana dan prasarana yang belum layak, Hal ini mungkin disebabkan oleh penyaluran anggaran pendidikan dari Pemerintah Pusat kepada Pemerintah Daerah yang belum merata akibat dari tindak praktik korupsi, sehingga sarana dan prasarana yang seharusnya baik dan berkualitas menjadi tidak sesuai dengan spesifikasi dan kualitas yang telah dianggarkan oleh Pemerintah Pusat.

\section{Proses mengajar}

Dalam pendidikan diI ndonesia adalah setiap anak tidak bisa yakin bahwa dia berbeda dengan yang lainnya.terdapat cara mendidik siswa yaitu dengan cara menghafal, Saya tidak setuju karena suatu saat akan lupa,seharusnya guru membuat siswa menjadi paham lalu mengetahui cara pengaplikasian ilmu tersebut. Padahal kunci dari proses pembelajaran sebenarnya adalah bagaimana kita mampu memahami konsep dari topik yang kita pelajari dan mampu mengaplikasikannya dalam kehidupan sehari-hari. Tidak perlu dihapal mati luar dalam. Efek dari kesalahan pola pikir bisa kita lihat sendiri sekarang.

\section{Guru yang seharusnya menjadi idola murid-muridnya}

Kunci utama perbaikan pendidikan akan selalu kembali kepada orang yang berdiri di depan kelas, guru. Guru yang baik akan menghasilkan murid-murid yang baik. Sayangnya masih banyak guru di Indonesia yang masih memahami pekerjaannya hanya sebatas mengajar, bukan mendidik. Akibatnya jelas, fokus dan orientasi guru terpaku pada nilai, bagaimana si anak mendapat nilai yang bagus, bukan pada perkembangan karakter si anak, perkembangan kematangan mental, 


\section{Widyantoko}

penanaman nilai-nilai kehidupan, pemahaman potensi anak, kedekatan emosional antara guru dan murid. Sekali lagi, pendidikan adalah sebuah proses yang tidak akan pernah berhenti. Pendidikan tidak terbatas dari jenjang di sekolah. Pendidikan bukan hanya soal UN, standarisasi, dan nilai bagus.

\section{Perkembangan kurikulum}

Bergantinya kurikulum KTSP menjadi kurtilas membuat guru harus dapat beradaptasi dengan cepat atas perkembangan kurikulum. Guruguru yang belum terbiasa dengan metode pengajaran baru yang diterapkan pemerintah. Apalagi metode penilaian sama sekali berbeda dibandingkan dengan kurikulum lama.

\section{KESIMPULAN}

Dalam menjadi warga Negara Indonesia kita mendapat hak untuk mendapatkan pendidikan yang layak, karena hal tersebut adalah tujuan bangsa Indonesia yang telah tertuang dalam pembukaan UUD 1945 dengan tujuan agar tercipta manusia-manusia cerdas yang siap memajukan bangsa ini. Maka pendidikan adalah hak setiap warga negara tanpa pandang bulu membedakan apakah dia kaya atau miskin, apakah dia dari jawa atau papua, apakah dia bodoh atau pintar, karena setiap warga Negara berhak mendapat pendidikan untuk mengembangkan dirinya sesuai dengan ini pasal $28 \mathrm{C}$ ayat 1 . Kurangnya pemerataan dan carut-marut pendidikan kita selama ini disebabkan pendidikan dikelola tidak secara profesional. Terjadi bongkar pasang kebijakan secara tidak konsisten, misalnya; penerapan kurikulum CBSA, Kurikulum Berbasis Kompetensi (KBK) dan kurikulum KTSP. Penggantian nama dari SMA ke SMU kembali lagi ke SMA, sebelum diadakan evaluasi hasil pelaksanaannya. Maka dari itu untuk pelaksanaan pendidikan diperlukan adanya peran serta kita semua sebagai elemen masyarakat dan pemerintah agar terlaksananya pendidikan bagi semua kalangan masyarakat dimanapun mereka berada.

\section{SARAN}

Pemerintah seharusnya lebih memperhatikan dan menangani dengan lebih serius lagi masalah yang sedang dihadapi dunia pendidikan, misalnya masalah dana subsidi pendidikan yang masih kurang, agar setiap warga Negara khususnya yang kurang mampu dapat merasa terbantu untuk mendapat pendidikan. Sehingga semua kalangan dapat mendapat pendidikan yang merata. Diperlukan juga peran serta dari seluruh elemen masyarakat dalam pendidikan agar terlaksana pendidikan 
bagi semua kalangan, sehingga tercipta masyarakat yang cerdas dan dapat selalu memajukan bangsa indonesia.

\section{REFERENSI}

Depdiknas, Rencana Strategi Departement pendidikan Nasional 20052009. Jakarta: Pusat Informasi dan Humas Depdiknas, 2005.

Setiardja, Gunawan. 1993. Hak-hak Asasi Manusia Bedasarkan Ideologi Pancasila. Yogyakarta : Kanisus

Soedijarto.2013. Kurikulum, Sistem Evaluasi, dan tenaga Pendidikan Sebagai Unsur Strategis Dalam Penyelenggraaan Satu Sistem Pendidikan Nasional.Makalah. Disajikan dalam pertemuan dengan FPP-DPRRI, Jakarta, 30 Januari 2013.

Soegito, dkk. Pendidikan Pancasila. Semarang : UNNES Press

Pidarta, Prof. Dr. Made. 2004. Management Pendidikan Indonesia. Jakarta. PT Rineka Cipta

Nuryanata, Made. 2010. Pembelajaran Masa Kini. Jakarta : Sekarmita

Satmoko, Landasan Kependidikan, Semarang: IKIP Semarang. Press, 1996

Evaluasi Sistem Pendidikan Nasional Indonesia- Faculty of Law, Jurnal Pendidikan Indonesia(JPI) Vol 6, No 1 (2017) 
Widyantoko

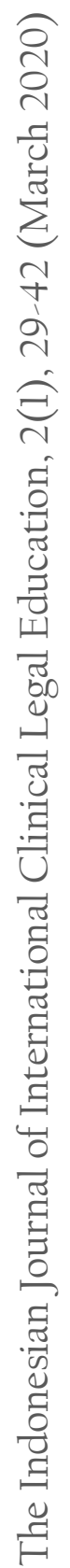

